CRYSTALLOGRAPHIC COMMUNICATIONS

ISSN 2056-9890

Received 1 March 2016

Accepted 11 March 2016

Edited by M. Weil, Vienna University of Technology, Austria

Keywords: crystal structure; spinel; Mössbauer spectroscopy; geoscience.

CCDC reference: 1463892

Supporting information: this article has supporting information at journals.iucr.org/e

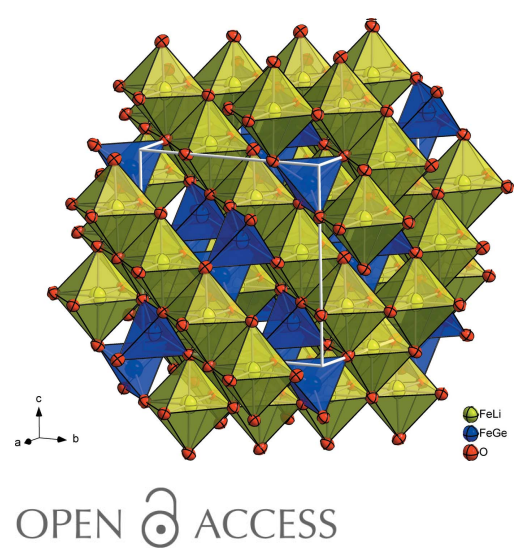

\section{Crystal structure of spinel-type $\mathrm{Li}_{0.64} \mathrm{Fe}_{2.15} \mathrm{Ge}_{0.21} \mathrm{O}_{4}$}

\author{
Günther J. Redhammer* and Gerold Tippelt
}

University of Salzburg, Department Chemistry and Physics of Materials, Hellbrunnerstrasse 34, 5020 Salzburg, Austria. *Correspondence e-mail: guenther.redhammer@sbg.ac.at

Spinel-type $\mathrm{Li}_{0.64} \mathrm{Fe}_{2.15} \mathrm{Ge}_{0.21} \mathrm{O}_{4}$, lithium diiron(III) germanium tetraoxide, has been formed as a by-product during flux growth of an $\mathrm{Li}-\mathrm{Fe}-\mathrm{Ge}$ pyroxene-type material. In the title compound, lithium is ordered on the octahedral $B$ sites, while $\mathrm{Ge}^{4+}$ orders onto the tetrahedral $A$ sites, and iron distributes over both the octahedral and tetrahedral sites, and is in the trivalent state as determined from Mössbauer spectroscopy. The oxygen parameter $u$ is 0.2543 ; thus, the spinel is close to having an ideal cubic closed packing of the $\mathrm{O}$ atoms. The title spinel is compared with other $\mathrm{Li}$ - and $\mathrm{Ge}$-containing spinels.

\section{Chemical context}

The minerals of the spinel group are widely occurring compounds in the geosphere and are important not only in geoscience but also in many other disciplines. In recent years, in particular, Li-containing spinels like $\mathrm{LiMn}_{2} \mathrm{O}_{4}$ or $\mathrm{Li}_{0.5} \mathrm{Fe}_{2.5} \mathrm{O}_{4}$ have attracted much interest in battery technology as possible candidates for cathode materials in lithium ion secondary batteries (Liu et al., 2014; Patil et al., 2016; Thackeray et al., 1983). The ideal spinel structure consists of a closed packing of anions $X$, with one-eighth of the tetrahedral interstices and one-half of the octahedral interstices occupied by the cations. The vast majority of spinels crystallize in the space group $F d \overline{3} m$. Here the cations in tetrahedral coordination occupy special position $8 a$ (point symmetry $\overline{4} 3 m$, at $\frac{1}{8}, \frac{1}{8}, \frac{1}{8}$ ), while the octahedrally coordinated cations reside on special position $16 d$ (point symmetry $\overline{3} m$ at $\frac{1}{2}, \frac{1}{2}, \frac{1}{2}$ ). The anions are at equipoint position $32 e$, which requires one positional parameter, often denoted as the $u$ parameter. For $u=0.25$, an ideal cubic closed packing of anions is realized and the octahedral bond length is 1.155 times larger than the tetrahedral one. Following Hill et al. (1979), variations in $u$ reflect the adjustment of the structure to accommodate cations of different size in octahedral and tetrahedral positions. Increasing the value of $u$ above 0.25 moves the anions away along [111] from the nearest tetrahedral cation, thereby increasing the size of the tetrahedron at the extent of the size of the octahedron. The majority of the spinels can be described with the general formula $A B_{2} \mathrm{O}_{4}$, with the $A$ and $B$ cations having the formal charges $A=2$ and $B=3$ (2,3 spinels) or $A=4$ and $B=2(4,2$ spinels). The perfect normal spinel is one in which the single $A$ cation occupies the tetrahedral site and the two $B$ cations reside at the two equivalent octahedral positions. Introducing parentheses, i.e. (...) and brackets, i.e. [...], for tetrahedral and octahedral coordination, respectively, one may write the normal spinels in the form $(A)\left[B_{2}\right] \mathrm{O}_{4}$. In contrast, the complete inverse spinel has a cationic distribution of $(B)[A B] \mathrm{O}_{4} \quad$ (O'Neill \& Navrotsky, 1983). More detailed reviews on the spinel structure and crystal chemistry can be 
found, for example, in Biagioni \& Pasero (2014), Harrison \& Putnis (1998), Hill et al. (1979) and O’Neill \& Navrotsky (1983).

Germanium-containing spinels are considered to belong to the normal spinels, with a full ordering of $\mathrm{Ge}^{4+}$ onto the tetrahedral $A$ site, while metal cations $M$ order onto the octahedral $B$ sites. This was demonstrated by, among others, Von Dreele et al. (1977) for $\mathrm{GeMg}_{2} \mathrm{O}_{4}$ and Welch et al. (2001) for the mineral brunogeierite $\left(\mathrm{GeFe}_{2} \mathrm{O}_{4}\right)$. For $\mathrm{LiMn}_{2} \mathrm{O}_{4}$ and $\mathrm{LiNi}_{0.5} \mathrm{Mn}_{1.5} \mathrm{O}_{4}$, which represent excellent cathode materials, it was found that $\mathrm{Li}^{+}$orders onto the tetrahedral site (Berg et al., 1998; Liu et al., 2014). Also for $\mathrm{LiCrGeO}_{4}$, Touboul \& Bourée (1993) reported an almost exclusive ordering of $\mathrm{Li}^{+}$for the tetrahedral site, while $\mathrm{Cr}^{3+}$ and $\mathrm{Ge}^{4+}$ occupy the octahedral sites. Different to this is the spinel $\mathrm{Li}_{0.5} \mathrm{Fe}_{2.5} \mathrm{O}_{4}$. This compound is an inverse spinel in which $\mathrm{Fe}^{3+}$ is ordered onto the tetrahedral site, while $\mathrm{Li}^{+}$and the remaining $\mathrm{Fe}^{3+}$ are distributed over the octahedral site (Hankare et al., 2009; Patil et al., 2016; Tomas et al., 1983). This cationic distribution is thus similar to that in the inverse spinel magnetite, $\mathrm{FeFe}_{2} \mathrm{O}_{4}$ (Fleet, 1981).

During the synthesis of $\mathrm{Li}-\mathrm{Fe}-\mathrm{Ge}$ pyroxenes (Redhammer et al., 2009, 2010), black octahedral-shaped single crystals were frequently obtained, which turned out to be a spinel-type compound with significant $\mathrm{Li}^{+}$and small $\mathrm{Ge}^{4+}$ concentrations. We present here the structure refinement and ${ }^{57} \mathrm{Fe}$ Mössbauer spectroscopic characterization of these crystals.

\section{Structural commentary}

The structure of the title compound is shown in Fig. 1. The site-occupation refinement indicates that $\mathrm{Li}^{+}$orders onto the octahedral $B$ site, while $\mathrm{Ge}^{4+}$ is found on the tetrahedral $A$ site, indicating a partial inverse spinel arrangement; iron is

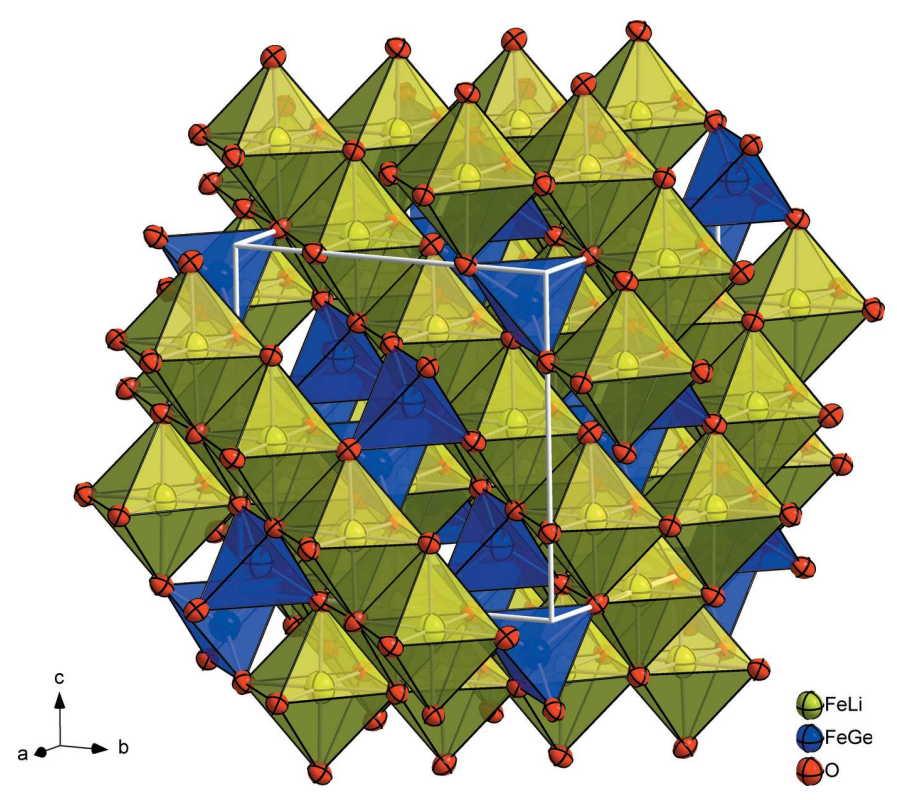

Figure 1

Polyhedral drawing of the spinel-type structure of the title compound. Anisotropic displacement parameters are drawn at the $95 \%$ probability level. distributed over both sites. The derived crystal chemical formula of the title compound is thus $\left(\mathrm{Fe}^{3+}{ }_{0.79} \mathrm{Ge}^{4+}{ }_{0.21}\right)$ $\left[\mathrm{Li}^{+}{ }_{0.64} \mathrm{Fe}^{3+}{ }_{1.36}\right] \mathrm{O}_{4}$, with the valence state of iron determined from ${ }^{57} \mathrm{Fe}$ Mössbauer spectroscopy (see below). This formula is balanced in charge and agrees very well with the chemical composition determined from electron microprobe analysis. Generally, the title compound is similar to the $\mathrm{Li}_{0.5} \mathrm{Fe}_{2.5} \mathrm{O}_{4}$ spinel-type materials. The shift of $\mathrm{Li}^{+}$to the octahedral site, for example, in comparison with $\mathrm{LiCrGeO}_{4}$ or $\mathrm{LiMn}_{2} \mathrm{O}_{4}$, can be explained by the strong preference of $\mathrm{Fe}^{3+}$ for the tetrahedral site. Based on the concept of crystal field stabilization energy, Miller (1959) theoretically calculated octahedral site preference energies which gave a stronger preference of $\mathrm{Fe}^{3+}$ for the tetrahedral site as compared, for example, to $\mathrm{Li}^{+}$or $\mathrm{Mn}^{3+}$.

The lattice parameter of the title compound [8.2903 (3) A] is smaller in comparison with, for example, magnetite $\mathrm{Fe}_{3} \mathrm{O}_{4}$ [ $a=8.3941$ (7) $\AA$; Fleet, 1981], but larger than that observed in the $\mathrm{Li}$ spinels $\mathrm{LiCrGeO}_{4}[a=8.1976$ (1) $\AA$; Touboul \& Bourée, 1993] or $\mathrm{LiMn}_{2} \mathrm{O}_{4}$ and $\mathrm{LiNi}_{0.5} \mathrm{Mn}_{1.5} \mathrm{O}_{4}(a=8.243$ and $8.1685 \AA$, respectively; Liu et al., 2014). This is due mainly to the high amount of $\mathrm{Fe}^{3+}$ at the $A$ sites, which has a larger ionic radius than $\mathrm{Ge}^{4+}, \mathrm{Ni}^{3+}$ or $\mathrm{Mn}^{3+/ 4+}$ (Shannon \& Prewitt, 1969). The oxygen parameter $u=0.2543$ is close to the ideal value for cubic closed packing, reflecting some distinct differences to the spinels which have the $A$ site fully occupied by $\mathrm{Li}^{+}$. In the title compound, the bond length of the tetrahedrally coordinated site $T$ is 1.857 (2) $\AA$, which is distinctly smaller than in, for example, $\mathrm{LiMn}_{2} \mathrm{O}_{4}$, with the tetrahedral site being fully occupied by $\mathrm{Li}^{+}$. The $T-\mathrm{O}$ bond length is also smaller than in magnetite (Fleet, 1981) or $\mathrm{Li}_{0.5} \mathrm{Fe}_{2.5} \mathrm{O}_{5}$ (Tomas et al., 1983), with values of 1.8889 (9) and 1.880 (5) $\AA$, respectively. In $\mathrm{GeFe}_{2} \mathrm{O}_{4}$, the $T-\mathrm{O}$ bond length is only 1.771 (2) $\AA$ and this smaller value of $T-\mathrm{O}$ compared to, for example, magnetite is due to the substitution of $\mathrm{Ge}^{4+}$ onto the $A$ site and can be seen as additional proof for the correctness of the derived cationic distribution.

The bond length involving the octahedrally coordinated site $M$ is 2.0373 (11) $\AA$, which is 1.07 times larger than the bond length involving the tetrahedrally coordinated site. The $M-\mathrm{O}$

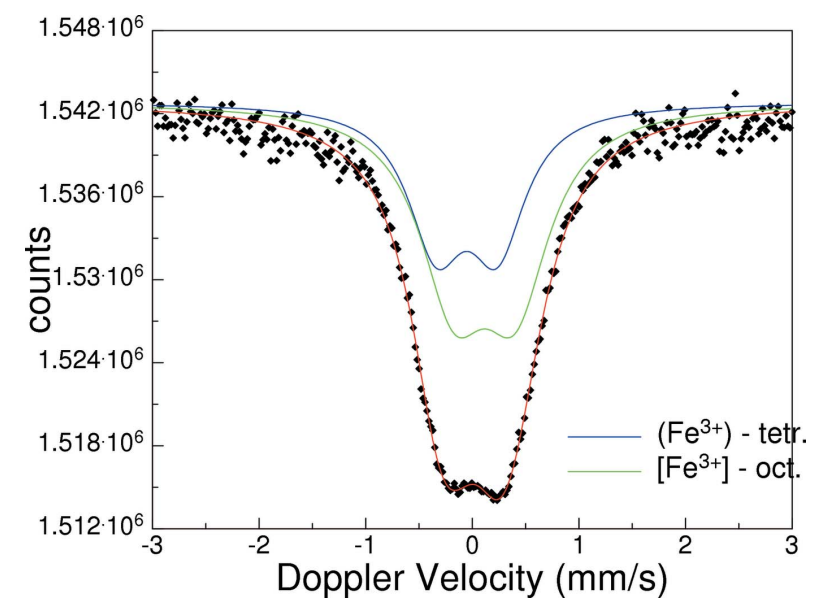

Figure 2

${ }^{57} \mathrm{Fe}$ Mössbauer spectrum of the title compound, recorded at $740 \mathrm{~K}$. 
Table 1

Experimental details.

\begin{tabular}{|c|c|}
\hline \multicolumn{2}{|l|}{ Crystal data } \\
\hline Chemical formula & $\mathrm{Li}_{0.64} \mathrm{Fe}_{2.15} \mathrm{Ge}_{0.21} \mathrm{O}_{4}$ \\
\hline$M_{\mathrm{r}}$ & 203.5 \\
\hline Crystal system, space group & Cubic, $F d \overline{3} m$ \\
\hline Temperature (K) & 298 \\
\hline$a(\AA)$ & $8.2903(3)$ \\
\hline$V\left(\AA^{3}\right)$ & $569.78(6)$ \\
\hline$Z$ & 8 \\
\hline Radiation type & Мо $K \alpha$ \\
\hline$\mu\left(\mathrm{mm}^{-1}\right)$ & 12.85 \\
\hline Crystal size $(\mathrm{mm})$ & $0.13 \times 0.12 \times 0.12$ \\
\hline \multicolumn{2}{|l|}{ Data collection } \\
\hline Diffractometer & Bruker SMART APEX CCD \\
\hline Absorption correction & $\begin{array}{l}\text { Multi-scan (SADABS; Bruker, } \\
\text { 2012) }\end{array}$ \\
\hline$T_{\min }, T_{\max }$ & $0.83,0.94$ \\
\hline $\begin{array}{l}\text { No. of measured, independent and } \\
\text { observed }[I>2 \sigma(I)] \text { reflections }\end{array}$ & $3046,118,114$ \\
\hline$R_{\text {int }}$ & 0.021 \\
\hline$(\sin \theta / \lambda)_{\max }\left(\AA^{-1}\right)$ & 0.940 \\
\hline \multicolumn{2}{|l|}{ Refinement } \\
\hline$R\left[F^{2}>2 \sigma\left(F^{2}\right)\right], w R\left(F^{2}\right), S$ & $0.018,0.042,1.37$ \\
\hline No. of reflections & 118 \\
\hline No. of parameters & 10 \\
\hline No. of restraints & 1 \\
\hline$\Delta \rho_{\max }, \Delta \rho_{\min }\left(\mathrm{e} \AA^{-3}\right)$ & $0.36,-0.67$ \\
\hline
\end{tabular}

Computer programs: APEX2 and SAINT (Bruker, 2012), SHELXL2014 (Sheldrick, 2015), DIAMOND (Brandenburg, 2006) and WinGX (Farrugia, 2012).

bond length is somewhat larger than 2.025 (3) $\AA$ in $\mathrm{Li}_{0.5} \mathrm{Fe}_{2.5} \mathrm{O}_{4}$ (Tomas et al., 1983). This agrees well with the observed higher $\mathrm{Li}$ content in the title compound, with the ionic radius for $\mathrm{Li}^{+}$in an octahedral coordination $(0.740 \AA)$ being larger than that of $\mathrm{Fe}^{3+}(0.645 \AA$; Shannon \& Prewitt, 1969), thus increasing the $M-\mathrm{O}$ distance. Magnetite has a mixed occupation of the octahedral sites, with both $\mathrm{Fe}^{2+}$ and $\mathrm{Fe}^{3+}$, thus having a larger $M-\mathrm{O}$ bond length of 2.0582 (9) $\AA$, while in $\mathrm{GeFe}_{2} \mathrm{O}_{4}$, all the $\mathrm{Fe}$ atoms are in a divalent state and an $M-\mathrm{O}$ bond length of 2.132 (2) $\AA$ is observed.

In order to quantify the valence state of iron in the title compound, a ${ }^{57} \mathrm{Fe}$ Mössbauer spectrum was recorded at $340 \mathrm{~K}$. It shows a broad, slightly asymmetric, doublet, which can be evaluated with two Lorentzian-shaped doublets (Fig. 2). The first doublet shows an isomer shift (IS) of -0.053 (17) $\mathrm{mm} \mathrm{s}^{-1}$ and a quadrupole splitting (QS) of 0.57 (3) $\mathrm{mm} \mathrm{s}^{-1}$, and can be assigned to the ferric iron on the tetrahedral site. The second doublet has a larger IS of $0.115(14) \mathrm{mm} \mathrm{s}^{-1}$ and an almost identical QS of 0.58 (2) $\mathrm{mm} \mathrm{s}^{-1}$, and is assigned to ferric iron at the octahedral site. No indications for ferrous iron are present. The QS values suggest low polyhedral distortion, which is almost identical in both sites. The relative area ratio of tetrahedral to octahedral sites is $38.6(8)$ to $61.4(9) \%$. Assuming a total amount of 2.15 formula units $\mathrm{Fe}^{3+}$, the results of Mössbauer spectroscopy give a cation distribution of $\left(\mathrm{Fe}^{3+}{ }_{0.83}\right)\left[\mathrm{Fe}^{3+}{ }_{1.32}\right]$, which is in good agreement with that obtained from the site-occupation refinement of the X-ray data. At room temperature, the title compound is magnetically ordered, as revealed by its ${ }^{57} \mathrm{Fe}$ Mössbauer spectrum.

\section{Synthesis and crystallization}

The spinel formed as a by-product during the synthesis of pyroxene-type $\mathrm{LiFeGe}_{2} \mathrm{O}_{6}$ in flux-growth experiments (Redhammer et al., 2010). For the synthesis of the pyroxene, $\mathrm{Li}_{2} \mathrm{CO}_{3}, \mathrm{Fe}_{2} \mathrm{O}_{3}$ and $\mathrm{GeO}_{2}$ in the stoichiometry of the compound and $\mathrm{Li}_{2} \mathrm{MoO}_{4} / \mathrm{LiVO}_{3}$ as a flux (mass ratio sample to flux $=1: 10$ ) were mixed together, heated to $1473 \mathrm{~K}$ in a platinum crucible, covered with a lid, held at this temperature for $24 \mathrm{~h}$ and cooled afterwards at a rate of $1.5 \mathrm{~K} \mathrm{~h}^{-1}$ to $973 \mathrm{~K}$. The experimental batch consisted of large pyroxene crystals and a distinct amount of black crystals with idiomorphic octahedral habit, up to $200 \mu \mathrm{m}$. Semi-quantitative EDX (energy-dispersive X-ray) analysis revealed iron and some germanium as the main elements; powder X-ray diffraction analysis revealed the crystals as a spinel-type material. An electron microprobe analysis on polished/embedded crystals (three different grains with five measurement points each) yielded a chemical composition of 84.86 (30) wt $\% \mathrm{Fe}_{2} \mathrm{O}_{3}$, $10.52(25) \mathrm{wt} \% \mathrm{GeO}_{2}$ and $4.62 \mathrm{wt} \% \mathrm{Li}_{2} \mathrm{O}$, with the latter calculated from the difference to 100 oxide $\%$. There is no evidence for Mo or $\mathrm{V}$ from the flux, nor for any other chemical elements. From the oxide percentage, a chemical formula of $\mathrm{Li}_{0.63(2)} \mathrm{Fe}_{2.18(1)} \mathrm{Ge}_{0.20(2)} \mathrm{O}_{4}$ was calculated, which is in good agreement with that obtained from the structure refinement. Individual crystals are homogeneous in composition, with no significant systematic variation from rim-core; also, there is no systematic variation in composition from crystal to crystal.

\section{Refinement}

Crystal data, data collection and structure refinement details are summarized in Table 1 . In a first stage of refinement, only iron was considered on the $A$ and $B$ sites, thereby allowing unconstrained refinement of the site-occupation factors. This gave a surplus of electron density (higher occupation than allowed by the multiplicity) at the tetrahedral site, while a lower occupation than possible was found for the octahedral site. From this it was concluded that Li enters the octahedral site and Ge enters the tetrahedral site. In the final refinements, it was assumed that both tetrahedral and octahedral sites are fully occupied, with $\mathrm{Fe}+\mathrm{Ge}=1$ as a restraint for the tetrahedral site and $\mathrm{Fe}+\mathrm{Li}=1$ for the octahedral site.

\section{References}

Berg, H., Thomas, J. O., Liu, W. \& Farrington, G. C. (1998). Solid State Ionics, 112, 165-168.

Biagioni, C. \& Pasero, M. (2014). Am. Mineral. 99, 1254-1264.

Brandenburg, K. (2006). DIAMOND. Crystal Impact GbR, Bonn, Germany.

Bruker (2012). APEX2, SAINT and SADABS. Bruker AXS Inc., Madison, Wisconsin, USA.

Farrugia, L. J. (2012). J. Appl. Cryst. 45, 849-854.

Fleet, M. E. (1981). Acta Cryst. B37, 917-920.

Hankare, P. P., Patil, R. P., Sankpal, U. B., Jadhav, S. D., Lokhande, P. D., Jadhav, K. M. \& Sasikala, R. (2009). J. Solid State Chem. 182, 3217-3221.

Harrison, R. J. \& Putnis, A. (1998). Surv. Geophys. 19, 461-520. 
Hill, R. J., Craig, J. R. \& Gibbs, G. V. (1979). Phys. Chem. Miner. 4, 317-339.

Liu, D., Zhu, W., Trottier, J., Gagnon, C., Barray, F., Guerfi, A., Mauger, A., Groult, H., Julien, C. M., Goodenough, J. B. \& Zaghib, K. (2014). RSC Adv. 4, 154-167.

Miller, A. (1959). J. Appl. Phys. 30, S24-S25.

O'Neill, H. S. C. \& Navrotsky, A. (1983). Am. Mineral. 68, 181194.

Patil, R. P., Patil, S. B., Jadhav, B. V., Delekar, S. D. \& Hankare, P. P. (2016). J. Magn. Magn. Mater. 401, 870-874.

Redhammer, G. J., Cámara, F., Alvaro, M., Nestola, F., Tippelt, G., Prinz, S., Simons, J., Roth, G. \& Amthauer, G. (2010). Phys. Chem. Miner. 37, 685-704.
Redhammer, G. J., Roth, G., Treutmann, W., Hoelzel, M., Paulus, W., André, G., Pietzonka, C. \& Amthauer, G. (2009). J. Solid State Chem. 182, 2374-2384.

Shannon, R. D. \& Prewitt, C. T. (1969). Acta Cryst. B25, 925-946.

Sheldrick, G. M. (2015). Acta Cryst. C71, 3-8.

Thackeray, M. M., David, W. I. F., Bruce, P. G. \& Goodenough, J. B. (1983). Mater. Res. Bull. 18, 461-472.

Tomas, A., Laruelle, P., Dormann, J. L. \& Nogues, M. (1983). Acta Cryst. C39, 1615-1617.

Touboul, M. \& Bourée, F. (1993). J. Mater. Chem. 3, 623-626.

Von Dreele, R. B., Navrotsky, A. \& Bowman, A. L. (1977). Acta Cryst. B33, 2287-2288.

Welch, M. D., Cooper, M. A. \& Hawthorne, F. C. (2001). Mineral. Mag. 65, 441-444. 


\section{supporting information}

Acta Cryst. (2016). E72, 505-508 [https://doi.org/10.1107/S205698901600414X]

Crystal structure of spinel-type $\mathrm{Li}_{0.64} \mathrm{Fe}_{2.15} \mathrm{Ge}_{0.21} \mathrm{O}_{4}$

\section{Günther J. Redhammer and Gerold Tippelt}

Computing details

Data collection: APEX2 (Bruker, 2012); cell refinement: SAINT (Bruker, 2012); data reduction: SAINT (Bruker, 2012); program(s) used to solve structure: coordinates from an isotypic structure; program(s) used to refine structure:

SHELXL2014 (Sheldrick, 2015); molecular graphics: DIAMOND (Brandenburg, 2006); software used to prepare material for publication: WinGX (Farrugia, 2012).

Lithium diiron(III) germanium tetraoxide

Crystal data

$\mathrm{Li}_{0.64} \mathrm{Fe}_{2.15} \mathrm{Ge}_{0.21} \mathrm{O}_{4}$

$M_{r}=203.5$

Cubic, $F d \overline{3} m$

Hall symbol: -F 4vw 2vw 3

$a=8.2903(3) \AA$

$V=569.78(6) \AA^{3}$

$Z=8$

$F(000)=771$

$D_{\mathrm{x}}=4.744 \mathrm{Mg} \mathrm{m}^{-3}$

Mo $K \alpha$ radiation, $\lambda=0.71073 \AA$

Cell parameters from 3046 reflections

$\theta=7.0-41.9^{\circ}$

$\mu=12.85 \mathrm{~mm}^{-1}$

$T=298 \mathrm{~K}$

Octahedron, black

$0.13 \times 0.12 \times 0.12 \mathrm{~mm}$

\section{Data collection}

Bruker SMART APEX CCD diffractometer

Radiation source: 3-circle diffractometer Graphite monochromator $\omega$-scan at 4 different $\varphi$ positions Absorption correction: multi-scan (SADABS; Bruker, 2012)

$T_{\min }=0.83, T_{\max }=0.94$

3046 measured reflections

118 independent reflections

114 reflections with $I>2 \sigma(I)$

$R_{\text {int }}=0.021$

$\theta_{\text {max }}=41.9^{\circ}, \theta_{\min }=7.0^{\circ}$

$h=-15 \rightarrow 14$

$k=-14 \rightarrow 10$

$l=-15 \rightarrow 13$

\section{Refinement}

Refinement on $F^{2}$

Least-squares matrix: full

$R\left[F^{2}>2 \sigma\left(F^{2}\right)\right]=0.018$

$w R\left(F^{2}\right)=0.042$

$S=1.37$

118 reflections

10 parameters

1 restraint

$w=1 /\left[\sigma^{2}\left(F_{\mathrm{o}}{ }^{2}\right)+(0.0139 P)^{2}+2.542 P\right]$ where $P=\left(F_{\mathrm{o}}^{2}+2 F_{\mathrm{c}}^{2}\right) / 3$

$(\Delta / \sigma)_{\max }<0.001$

$\Delta \rho_{\max }=0.36 \mathrm{e} \AA^{-3}$

$\Delta \rho_{\min }=-0.67$ e $\AA^{-3}$

Extinction correction: SHELXL2014

(Sheldrick, 2015)

Extinction coefficient: 0.0051 (6) 


\section{Special details}

Geometry. All esds (except the esd in the dihedral angle between two 1.s. planes) are estimated using the full covariance matrix. The cell esds are taken into account individually in the estimation of esds in distances, angles and torsion angles; correlations between esds in cell parameters are only used when they are defined by crystal symmetry. An approximate (isotropic) treatment of cell esds is used for estimating esds involving l.s. planes.

Fractional atomic coordinates and isotropic or equivalent isotropic displacement parameters $\left(\hat{A}^{2}\right)$

\begin{tabular}{llllll}
\hline & $x$ & $y$ & $z$ & $U_{\text {iso }} * / U_{\text {eq }}$ & Occ. $(<1)$ \\
\hline Fe1 & 0.5 & 0.5 & 0.5 & $0.00795(17)$ & $0.678(4)$ \\
Li1 & 0.5 & 0.5 & 0.5 & $0.00795(17)$ & $0.322(4)$ \\
Fe2 & 0.125 & 0.125 & 0.125 & $0.00573(17)$ & $0.795(3)$ \\
Ge2 & 0.125 & 0.125 & 0.125 & $0.00573(17)$ & $0.205(3)$ \\
O2 & $0.25434(14)$ & $0.25434(14)$ & $0.25434(14)$ & $0.0095(3)$ & \\
\hline
\end{tabular}

Atomic displacement parameters $\left(\AA^{2}\right)$

\begin{tabular}{lllllll}
\hline & $U^{11}$ & $U^{22}$ & $U^{33}$ & $U^{12}$ & $U^{13}$ & $U^{23}$ \\
\hline Fe1 & $0.00795(17)$ & $0.00795(17)$ & $0.00795(17)$ & $-0.00100(11)$ & $-0.00100(11)$ & $-0.00100(11)$ \\
Li1 & $0.00795(17)$ & $0.00795(17)$ & $0.00795(17)$ & $-0.00100(11)$ & $-0.00100(11)$ & $-0.00100(11)$ \\
Fe2 & $0.00573(17)$ & $0.00573(17)$ & $0.00573(17)$ & 0 & 0 & 0 \\
Ge2 & $0.00573(17)$ & $0.00573(17)$ & $0.00573(17)$ & 0 & 0 & 0 \\
O2 & $0.0095(3)$ & $0.0095(3)$ & $0.0095(3)$ & $0.0010(3)$ & $0.0010(3)$ & $0.0010(3)$ \\
\hline
\end{tabular}

Geometric parameters $\left(\AA,{ }^{\circ}\right)$

\begin{tabular}{|c|c|c|c|}
\hline $\mathrm{Fe} 1-\mathrm{O} 2^{\mathrm{i}}$ & $2.0373(11)$ & $\mathrm{Fe} 1-\mathrm{Fe} 1^{\mathrm{ii}}$ & $2.9311(1)$ \\
\hline $\mathrm{Fe} 1-\mathrm{O} 2^{\mathrm{ii}}$ & $2.0373(11)$ & $\mathrm{Fe} 2-\mathrm{O} 2^{\text {vii }}$ & $1.857(2)$ \\
\hline $\mathrm{Fe} 1-\mathrm{O} 2^{\mathrm{iii}}$ & $2.0373(11)$ & $\mathrm{Fe} 2-\mathrm{O} 2^{\text {viii }}$ & $1.857(2)$ \\
\hline $\mathrm{Fe} 1-\mathrm{O} 2^{\mathrm{iv}}$ & $2.0373(11)$ & $\mathrm{Fe} 2-\mathrm{O} 2^{\text {ix }}$ & $1.857(2)$ \\
\hline $\mathrm{Fe} 1-\mathrm{O} 2^{\mathrm{v}}$ & $2.0373(11)$ & $\mathrm{Fe} 2-\mathrm{O} 2$ & $1.857(2)$ \\
\hline $\mathrm{Fe} 1-\mathrm{O} 2^{\mathrm{vi}}$ & $2.0373(11)$ & & \\
\hline $\mathrm{O} 2^{\mathrm{i}}-\mathrm{Fe} 1-\mathrm{O} 2^{\mathrm{ii}}$ & 180 & $\mathrm{O} 2^{\mathrm{ii}}-\mathrm{Fe} 1-\mathrm{O} 2^{\mathrm{vi}}$ & $87.96(7)$ \\
\hline $\mathrm{O} 2^{\mathrm{i}}-\mathrm{Fe} 1-\mathrm{O} 2^{\mathrm{iii}}$ & $87.96(7)$ & 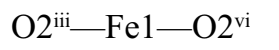 & $92.04(7)$ \\
\hline 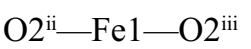 & $92.04(7)$ & $\mathrm{O} 2^{\mathrm{iv}}-\mathrm{Fe} 1-\mathrm{O} 2^{\mathrm{vi}}$ & $87.96(7)$ \\
\hline $\mathrm{O} 2^{\mathrm{i}}-\mathrm{Fe} 1-\mathrm{O} 2^{\mathrm{iv}}$ & $92.04(7)$ & $\mathrm{O} 2^{\mathrm{v}}-\mathrm{Fe} 1-\mathrm{O} 2^{\mathrm{vi}}$ & $180.00(7)$ \\
\hline $\mathrm{O} 2^{\mathrm{ii}}-\mathrm{Fe} 1-\mathrm{O} 2^{\mathrm{iv}}$ & $87.96(7)$ & 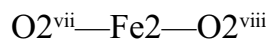 & 109.5 \\
\hline 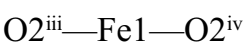 & 180 & $\mathrm{O} 2^{\mathrm{vii}}-\mathrm{Fe} 2-\mathrm{O} 2^{\mathrm{ix}}$ & 109.5 \\
\hline $\mathrm{O} 2^{\mathrm{i}}-\mathrm{Fe} 1-\mathrm{O}^{2}{ }^{\mathrm{v}}$ & $87.96(7)$ & $\mathrm{O} 2^{\mathrm{viii}}-\mathrm{Fe} 2-\mathrm{O} 2^{\mathrm{ix}}$ & 109.5 \\
\hline $\mathrm{O} 2^{\mathrm{ii}}-\mathrm{Fe} 1-\mathrm{O}^{\mathrm{v}}$ & $92.04(7)$ & $\mathrm{O} 2^{\mathrm{vii}-\mathrm{Fe} 2-\mathrm{O} 2}$ & $109.4710(10)$ \\
\hline 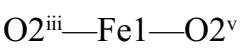 & $87.96(7)$ & $\mathrm{O} 2^{\text {viii- }-\mathrm{Fe} 2-\mathrm{O} 2}$ & 109.5 \\
\hline $\mathrm{O} 2^{\mathrm{iv}}-\mathrm{Fe} 1-\mathrm{O}^{\mathrm{v}}$ & $92.04(7)$ & $\mathrm{O} 2^{\mathrm{ix}}-\mathrm{Fe} 2-\mathrm{O} 2$ & $109.4710(10)$ \\
\hline $\mathrm{O} 2^{\mathrm{i}}-\mathrm{Fe} 1-\mathrm{O}^{2 \mathrm{vi}}$ & $92.04(7)$ & & \\
\hline
\end{tabular}

Symmetry codes: (i) $x+1 / 4, y+1 / 4,-z+1$; (ii) $-x+3 / 4,-y+3 / 4, z$; (iii) $x+1 / 4,-y+1, z+1 / 4$; (iv) $-x+3 / 4, y,-z+3 / 4$; (v) $-x+1, y+1 / 4, z+1 / 4$; (vi) $x,-y+3 / 4$, $-z+3 / 4$; (vii) $-x+1 / 4, y,-z+1 / 4$; (viii) $x,-y+1 / 4,-z+1 / 4$; (ix) $-x+1 / 4,-y+1 / 4, z$. 